https://doi.org/10.19195/0137-1150.173.14

Data przesłania artykułu: 22.08.2019

Data akceptacji artykułu: 13.02 .2020

\author{
ALICJA Z. NOWAK
}

Uniwersytet Jagielloński, Kraków, Polska

\title{
Parateksty drukowanych ksiąg cerkiewnych w metropolii kijowskiej jako media pamięci (druga połowa XVI-XVII wiek)
}

Literatura pełni wobec pamięci kulturowej funkcję specyficznego magazynu, który przechowuje wspomnienia. W XVI wieku rozpoczął się, zdaniem Jacques'a Le Goffa, etap dominacji pamięci pisemnej ${ }^{1}$. Zapisywanie na nośnikach opowieści, które przetrwają kolejne generacje, gwarantuje w miarę trwałą wersję historii, a ta z kolei stabilizuje, według Pierre'a Nory tożsamość społeczną 2 . Tym, co utrwalało pismo jako metaforę pamięci, było pojawienie się i upowszechnienie druku ${ }^{3}$.

Drukarstwo cyrylickie rozpoczęło się w Krakowie pod koniec XV wieku, zaledwie kilka dziesięcioleci po wytłoczeniu pierwszej na świecie księgi łacińską czcionką. Popularne stało się w Rzeczypospolitej od drugiej połowy XVI wieku. Większość wydanych do końca XVII stulecia ksiąg w metropolii kijowskiej miała charakter religijny, znaczna część przeznaczona była do celów liturgicznych. Druki zazwyczaj odznaczały się bogatą ramą wydawniczą. Najczęściej otwierały ją takie parateksty, jak przedstawienia herbów i heraldyczne wiersze, listy dedykacyjne oraz przedmowy, które mimo swojej lokalizacji w obrębie cerkiewnej księgi pełniły różne funkcje ${ }^{4} \mathrm{i}$ były ważnymi mediami pamięci.

1 Jacques Le Goff przedstawia rozwój pamięci opierając się w klasyfikacji na przeważających w różnych epokach mediach, por. idem, Historia i pamięć, przeł. A. Gronowska, J. Stryjczyk, Warszawa 2007, s. 105.

2 Za: M. Saryusz-Wolska, Wprowadzenie, [w:] Pamięć zbiorowa i kulturowa wspótczesna perspektywa niemiecka, red. M. Saryusz-Wolska, Kraków 2009, s. 20.

3 J. Tobaszewska, Od literatury jako medium pamięci do poetyki pamięci. Kategoria pamięci kulturowej w badaniach nad literatura, „Pamiętnik Literacki” 104, 2013, z. 4, s. 54.

4 Paratekst rozumiemy, zgodnie z ustaleniami Gérarde'a Genette'a, jako tekst-akompaniament tekstu zasadniczego, jego przedsionek i granicę. Analizie poddaliśmy jedynie wybrane parateksty, które badacz nazywał piśmiennymi (oprócz analizowanych w artykule listów dedykacyjnych 
Analizowane w artykule parateksty towarzyszące szesnastowiecznym drukom cerkiewnym wytłoczonym w Ostrogu i Dermaniu są znane badaczom i obecne $\mathrm{w}$ wielu antologiach ukraińskiej literatury. Istnieją reedycje siedemnastowiecznych paratekstów z ksiąg wydawanych w typografii kijowsko-pieczerskiej. Lwowskie listy dedykacyjne, eskortujące edycje przygotowane w warsztacie uspieńskiego bractwa stauropigialnego i prywatnego wydawcy Michała Ślozki, nadal oczekują na wydanie i naukowe opracowanie.

Wiersze herbowe i listy dedykacyjne na ogół utrwalały pamięć o osobach zaangażowanych w edycję księgi, przedmowy — częściej upamiętniały jej autorów, redaktorów, tłumaczy $\mathrm{i}$ inne osoby, które przyczyniły się do powstania zasadniczej części księgi.

Wsparcie udzielane przez możnych Cerkwi środowiskom pracującym dla odnowy religijnej było niezwykle istotne dla rozwoju życia duchowego i kultury ruskiej w ogóle. Dlatego upamiętnienie patrona było formą dziękczynienia za umożliwienie druku, strategią zdobywania dalszej jego przychylności, a ponadto sposobem na pozyskanie nowych źródeł finansowania od tych, którzy zechcą go naśladować.

Istotę tej wielofunkcyjności dobrze ilustruje między innymi ofiarowanie z lwowskiego Oktoicha (Октwихъ) z 1630 roku. Braccy autorzy listu dedykacyjnego wyrazili ją słowami autorytetów: Seneki, który uwiecznienie osoby uznawał za wartościowy sposób składania podzięki, i Jana Złotoustego, określającego pamięć w 25. homilii komentującej Ewangelię Mateusza „najdoskonalszym stróżem dobrych uczynków":

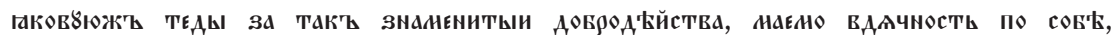

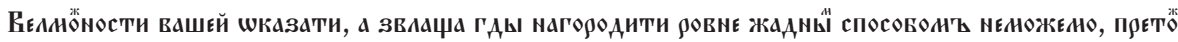

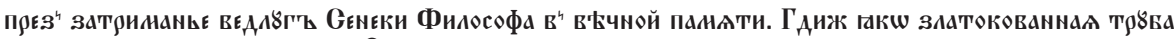

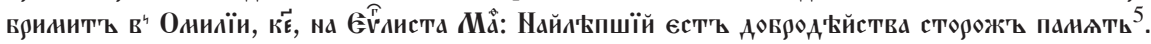

i przedmowy były to wprowadzenie, motto, epilog, przypisy), choć za takie uznawał także ilustracje (paratekst ikoniczny) oraz typografię i kompozycję. Mogły one pochodzić od redaktora, drukarza, wydawcy i innych osób zaangażowanych w przygotowanie edycji dzieła lub od autora książki, por. I. Loewe, Gatunki paratekstowe w komunikacji medialnej, Katowice 2007, s. 12-16. Niektórzy badacze słusznie uważają, że autorskie teksty to na ogół metateksty, które tworzą integralną część dzieła, są tym, czego w przeciwieństwie do paratekstu „od korpusu oderwać się nie da, bo stanowi z nim całość", por. ibidem, s. 76-77. Jednak jedyny analizowany w artykule autorski list dedykacyjny Joanicjusza Galatowskiego, który poprzedzał wyłącznie trzecią edycję zbioru jego kazań, wymyka się tej klasyfikacji. Jest to tekst autorski a zarazem fakultatywny, niebędący konieczną częścią zbioru, dlatego nie wprowadzamy rozróżniającego terminu „metatekst”.

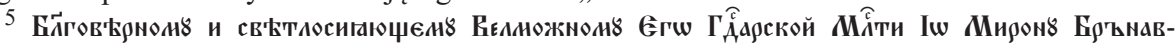

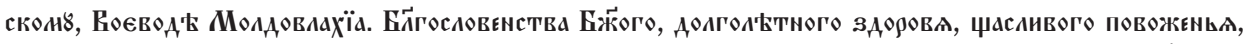

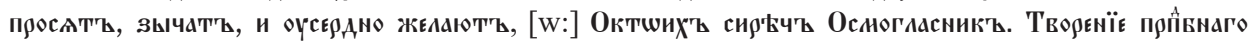

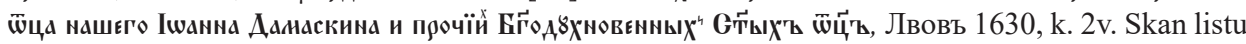
dedykacyjnego wraz z przekładem na język polski (aneks) dołączony został do artykułu Mirosława Piotra Kruka, ,,Oktoich lwowski” z 1630 r. Historyczne i kulturowe zwiazki między Rzeczapospolita, Mołdawia i Księstwem Moskiewskim, „Porta Aurea” 7-8, 2009, s. 45-108. 
Opiewany w dedykacji wojewoda Miron Barnowski był sławiony za wkład w odbudowę zniszczonej pożarem typografii, fundację wielu cerkwi i monasterów oraz często udzielaną jałmużnę ${ }^{6}$. Jak przekonywali braccy autorzy paratekstu, dobroć i hojność patrona skłoniła ich do wspominania jego imienia w trakcie codziennej modlitwy oraz rozgłaszania jego „znamienitych dobrodziejstw”, tak aby „sława Wielmożności mości waszej wiecznie i w wielu miejscach słynęła”, a o uczynkach nie zapominali potomni:

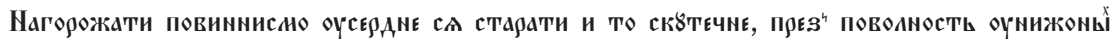
ПОСА४Г

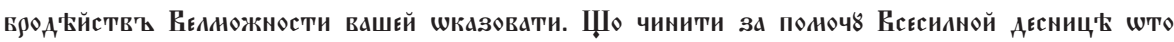

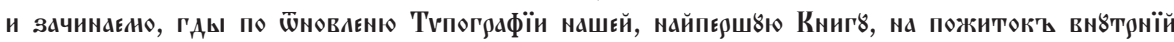

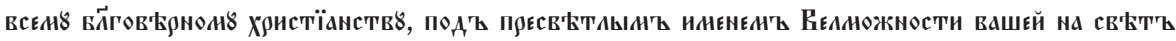

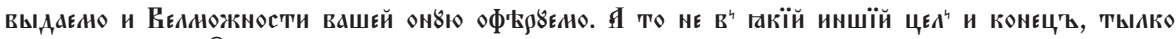

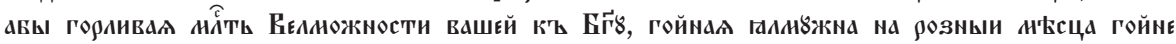

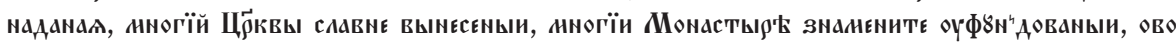

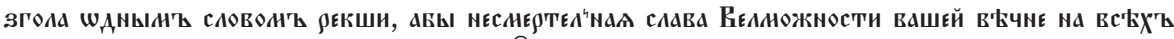





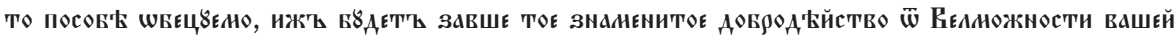
нӓ ШКАЗАнноИ В

Podobnie jak osobno wydawane wówczas pochwały możnych patronów paratekstowe laudacje wspierał popularny w renesansie motyw non omnis moriar. Autorzy listów i wierszy poddawali refleksji koncepcję nieśmiertelności sławy zdobywanej dzięki chwalebnym czynom. Jednocześnie sami przyczyniali się do ich uwiecznienia wśród kilku pokoleń odbiorców księgi powielonej w wielu egzemplarzach.

Zastanawiając się nad skutecznością zastosowanej przez brackich wydawców strategii komemoracji, należy uwzględnić fakt, że medium rozsławiającym imię wojewody i przechowującym pamięć o nim były parateksty pochodzące jedynie z części nakładu lwowskiego Oktoicha. Ukazał się on bowiem z różnymi wariantami wierszy i listów dedykacyjnych do możnych patronów. Byli wśród nich Aleksander Bałaban, Mojżesz Mohyła, Piotr Mohyła oraz Katarzyna Bohowitynowa-Jarmolińska. Tak postępowali także inni wydawcy i drukarze, uzyskujący wsparcie z różnych źródeł (między innymi Cyryl Trankwilion Stawrowecki, Melecjusz Smotrycki). Na kartach starych druków uwieczniono imiona wielu patronów, a adresy listów zmieniały się nawet $\mathrm{w}$ obrębie jednej edycji. Niemniej jednak do stałych elementów laudacji należały: propagowany model postępowania, wzorzec osobowy hojnego mecenasa, darczyńcy i opiekuna — ważny dla rozwoju religij-

${ }^{6} \mathrm{Na}$ temat wsparcia udzielanego bractwu lwowskiemu i całej Cerkwi prawosławnej przez wojewodę Mirona Barnowskiego z Mohyłów (hospodar mołdawski w latach 1626-1629 i 1633) oraz innych przedstawicieli tego rodu między innymi na podstawie omawianego listu dedykacyjnego por. M. Kruk, ,, Oktoich lwowski” z 1630 r...

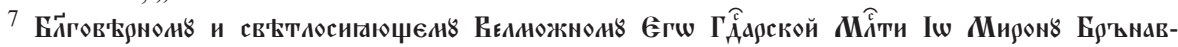
cкон18..., k. 2v-3. 
no-kulturalnego. Podobny cel przyświecał zapewne także tym wydawcom, którzy w tekstach ramy wydawniczej wskazywali patronat króla polskiego. Choć obejmował on głównie potwierdzenie otrzymanego wcześniej pozwolenia na druk, to jednak wzmacniał autorytet księgi i miał zabezpieczać dalszą opiekę władcy.

W najdawniejszych ofiarowaniach dla ruskich szlachciców z ksiąg drukowanych oprócz ideału religijnej opieki i kulturalnego mecenatu dostrzec można także inne upamiętniane treści związane $\mathrm{z}$ patronatem $\mathrm{i}$ ważne $\mathrm{w}$ procesie kształtowania kolektywnej tożsamości.

Jedną z wyraźnie zarysowanych już w XVI wieku tendencji było zakorzenianie ówczesnych książęcych rodów w odległej przeszłości, sięgającej czasów Rusi Kijowskiej. Jak zaważyła Natalia Jakowenko, po unii lubelskiej w Rzeczypospolitej do tworzenia ruskiego „terytorium z historią" przyczyniła się heraldyka ${ }^{8}$. Tacy twórcy jak Bartosz Paprocki, prezentując w pracy Herby rycerstwa polskiego (1584) pochodzenie rodu Ostrogskich i emblemat książąt z „ruską pogonią,", czyli przedstawieniem św. Jerzego, wskazywali ruskie jego korzenie ${ }^{10}$. Koncept ten został następnie rozpropagowany przez polskich ${ }^{11}$ i ruskich panegirystó ${ }^{12}$, służąc bieżącym interesom. Niepotwierdzona teza o dawnym pochodzeniu Ostrogskich $^{13} \mathrm{i}$ innych rodów była zatem budulcem pamięci kulturowej w wielonarodowym państwie. Była to przeszłość modelowana, która miała być zapamiętana i choć nie wspierała się na faktach, to jednak była ważnym czynnikiem integrują-

${ }^{8} \mathrm{Na}$ ten temat por. Н. Яковенко, Дзеркала ідентичності. Дослідження з історії уявлень та ідей в Україні XVI-початку ХVII століття, Київ 2012, s. 174.

${ }^{9}$ Por. ten zabytek na stronie https://polona.pl/item/herby-rycerztwa-polskiego-na-piecioroxiag-rozdzielone,NjcyNTM5NTQ/391/\#item [dostęp: 10.11.2018].

10 Н. Яковенко, Дзеркала ідентичності..., s. 172-173.

11 Ostrogscy w łacińskich laudacjach w XVI wieku (autorstwa na ogół nie Rusinów) byli wraz z Zasławskimi ukazywani jako potomkowie Rurykowiczów, wspominano także książęce pochodzenie innych rodów, Н. Яковенко, Топос „3'єднаних народів у панегіриках князям Острозьким і Заславським", [w:] еаdет, Паралельний світ. Дослідження з історії уявлень та ідей в Україні XVI-XVII cm., Київ 2002, s. 231-269; por. także еadem, Латина на службі києво-руській історії (,, Camoneae Borysthenides”, 1620 рік), [w:] Паралельний світ..., s. 282-284; Т. Chynczewska-Hennel, N. Jakowenko, Społeczeństwo - religia - kultura, [w:] Między soba. Szkice historyczne polsko-ukraińskie, red. T. Chynczewska-Hennel, N. Jakowenko, Lublin 2000, s. 135-137. W polskiej Kronice Macieja Stryjkowskiego, wydanej w 1582 roku, też opisane były ruskie rody, jednak kronikarz najbardziej apoteozował Ostrogskich; por. P. Borek, Ruś w Kronice Macieja Stryjkowskiego, [w:] Szlakami dawnej Ukrainy. Studia staropolskie, Kraków 2002, s. 56-57.

${ }^{12}$ Na przykład Hipacy Pociej w liście do Ostrogskiego z czerwca 1598 roku, a także Zachariasz Kopysteński w Palinodii; por. В. М. Ричка, Пригадування Русі (осмислення спадщини св. Володимира в українській суспільно-політичній думщі XVII cm.), „Український історичний журнал” 2012, nr 1, s. 31-32.

13 Por. Н. Яковенко, Дзеркала ідентичності..., s. 173, przyp. 32. Zdaniem Serhija Płochija pochodzenie Ostrogskich można wiązać z jedną z gałęzi rodu Giedyminowiczów i z polskimi książęcymi rodami; C. Плохій, Від князя до гетьмана. Образ „протектора” в українському православному письменстві (друга половина XVI-nерші десятиліття XVII cm.), [w:] Осягнення історії: Збірник праць на пошану професора М. П. Ковальського, red. Л. Винар, І. Пасічник, Острог-Нью-Йорк 1999, s. 428.

Slavica Wratislaviensia 173, 2020

(C) for this edition by CNS 
cym społeczeństwo ${ }^{14}$. Należy podkreślić, że ten sposób nobilitowania i wysuwania politycznych reprezentantów wpisywał się w ówczesne europejskie tendencje. Wśród południowych i zachodnich Słowian, którzy utracili suwerenność na rzecz Turcji lub Habsburgów, popularne były legendy dotyczące odrodzenia państwa pod przywództwem przedstawicieli rodów pochodzących z dawnych rządzących dynastii ${ }^{15}$.

Herb i wiersze poświęcone Ostrogskim, ukazywanym jako patroni prawosławia, spadkobiercy średniowiecznej Rusi i kontynuatorzy dawnej religijnej i kulturalnej spuścizny, znalazły się przede wszystkim w ramie wydawniczej druków, tłoczonych w warsztacie zorganizowanym przez kniazia Konstantyna Wasyla w końcu lat siedemdziesiątych XVI wieku. Najpierw w ostrogskiej edycji Bukwaru (Б8кваръ, 1578), następnie w słynnej Biblii (Библїа, 1581), nieco później również w Oktoichu z Dermania $(O x m a u \kappa z, 1604)^{16}$. Wiersze Herasyma Smotryckiego w ramie wydawniczej Pisma Świętego przypominały dawną świetność chrześcijańskiej kultury, której ponowne odrodzenie i aktualizacja znalazły swój wyraz w działalności Konstantyna Ostrogskiego, godnego następcy „przodków swoich”. Co więcej, zdaniem autora pochwały kniaź naśladował chrystianizacyjne dzieło Włodzimierza Chrzciciela i Jarosława Mądrego, albowiem do realizacji owych doniosłych i zbożnych zadań został wybrany przez niebiosa ${ }^{17}$ jak niegdyś ruscy książęta:

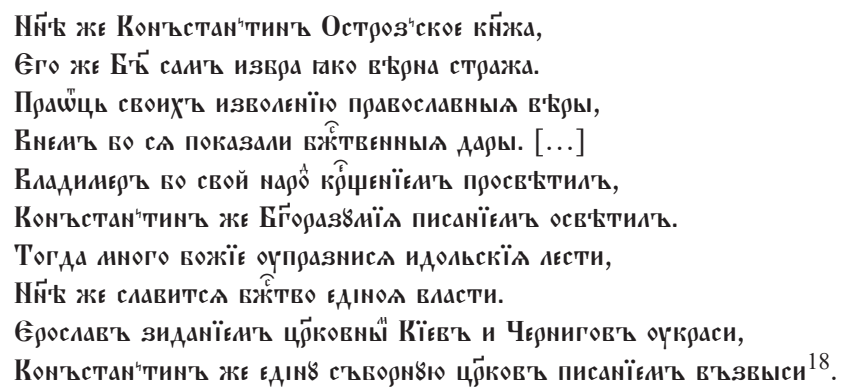

14 Jak celnie wyraził to badacz, ,wytwarza się specyficzna świadomość przeszłości, często daleka od rzeczywistych wydarzeń”, „istotnie służąca aktualnym interesom”, „fakty przestają być ważne, gdyż istotą staje się przeszłość zapamiętana", R. Traba, Wstęp, [w:] J. Assmann, Pamięć kulturowa. Pismo, zapamiętywanie i polityczna tożsamość w cywilizacjach starożytnych, przeł. A. Kryczyńska-Pham, wstęp i red. R. Traba, Warszawa 2008, s. 15-16.

15 С. Плохій, Від князя до гетьмана..., s. 426.

16 Autorem wiersza w tej edycji był Demjan Nalywajko. Warsztat ostrogski został prawdopodobnie przeniesiony do Dermania. Zdaniem badaczy świadczy o tym brak jednoczesnych wydań w Ostrogu oraz identyczne jak w Ostrogu czcionki; I. Огієнко, Історія украӥнського друкарства, Київ 2007, s. 263.

17 N. Jakowenko zwróciła uwagę na to, jak istotny dla wymowy tekstu był element interwencji Bożej, był to pierwszy jej zdaniem tekst panegiryczny, w którym wprost mówi się o Ostrogskich jako о wybrańcach Bożych, por. Н. Яковенко, Топос „3'єднаних народів..., s. 236. Motyw działania opatrzności Bożej (prowidencjalizm) w życiu Włodzimierza Wielkiego wykorzystał już metropolita Iłarion w jego pochwale, opisującej chrystianizacyjne dzieło kniazia w Stowie o prawie i łasce.

18 Герасим Аанилович [Смотрицкий], Вслкаго чина православный читаттелю, [W:] Бивлї̈ сире

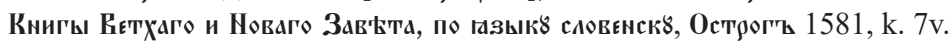


Przypadki legitymizacji historycznej na podstawie dziedzictwa ruskiego średniowiecza były rozpowszechnione w XVI wieku także w literaturze polemicz$n^{19}{ }^{19}$. Ponadto był to koncept ważny dla Rusi Moskiewskiej ${ }^{20}$.

W XVII wieku po wygaśnięciu linii Ostrogskich i młodszej ich linii — Zasławskich - uwaga i nadzieje prawosławnych intelektualistów zostały przeniesione na książąt Czetwertyńskich, o czym świadczą między innymi paratekstowe narracje w drukach kijowsko-peczerskich, na przykład w przedmowie Zachariasza Kopysteńskiego do Mów Jana Złotoustego z 1623 roku $^{21}$.

W latach dwudziestych XVII wieku po rekonstrukcji zdelegalizowanej po unii brzeskiej hierarchii cerkiewnej pojawia się też nowa idea, zgodnie z którą to Kozacy — nowi obrońcy prawosławia — są dziedzicami kijowskiej przeszłości ${ }^{22}$. Nawiązanie do epoki Rusi Kijowskiej było jednym z tych fundamentalnych, integrujących „historyczną pamięć” Rusinów w Rzeczypospolitej w czasach mohylańskich. Kulturowe formy upamiętniania łączyły różne media i domeny kultury ${ }^{23}$. Obejmowały one między innymi analizowany przez Aleksandra Naumowa proces wprowadzania panteonu ruskich świętych do powszechnej świadomości wiernych, tak aby „poczucie odrębności etnicznej i religijnej znalazło oparcie w sferze kulturowej"24. Działo się to między innymi za sprawą edycji wypuszczonych w typografii kijowsko-peczerskiej, takich jak Paterykon, Teraturgima ${ }^{25}$, ale

19 Prawosławni w przeciwieństwie do unitów eksponowali rolę Włodzimierza w doprowadzeniu do chrystianizacji ziemi ruskiej; por. В. М. Ричка, Пригадування Русі..., s. 29-30. Kijowscy intelektualiści w pierwszej połowie XVII wieku doprowadzili też do ożywienia kultu św. Włodzimierza Chrzciciela; ibidem, s. 34-38.

20 „Jeżeli uznać koncept samookreślenia i pamięci historycznej za użyteczne narzędzia w ustaleniu tożsamości narodowej danego narodu i jego dziedzictwa literackiego, należy przyjąć, że ten koncept działa na podobnej zasadzie zarówno w literaturze ukraińskiej, jak i rosyjskiej”, G. Brogi Bercoff, Ruś, Ukraina, Ruthenia, Wielkie Księstwo Litewskie, Rzeczpospolita, Moskwa, Rosja, Europa Środkowo-Wschodnia: o wielowarstwowości i polifunkcjonalizmie kulturowym, [w:] Contributi italiani al XIII Congresso Internazionale degli Slavisti (Ljubljana 15-21 agosto 2003), red. A. Alberti, M. Garzaniti, S. Garzonio, Firenze 2014, s. 355-356. Na temat obecnej od połowy XVII wieku na Ukrainie koncepcji pokrewieństwa moskiewskich carów w Rurykowiczami por. В. М. Ричка, Пригадування Русі..., s. 40-45.

21 Por. list dedykacyjny Zachariasza Kopysteńskiego do księcia Stefana Czetwertyńskiego, Н. Яковенко, Дзеркала ідентичності..., s. 175. W podobnym duchu utrzymane jest pogrzebowe kazanie po śmierci Eliasza Czetwertyńskiego wydane w Ławrze w 1641 roku.

22 Por. С. Плохій, Від князя до гетьмана..., s. 431; В. М. Ричка, Пригадування Русі..., s. 32-33.

23 Por. na ten temat M. Napiórkowski, Upamiętnienie, [w:] Modi memorandi. Leksykon kultury pamięci, red. M. Saryusz-Wolska, R. Traba, współp. J. Kalicka, Warszawa 2014, s. 509.

24 A. Naumow, Prawosławni święci I Rzeczypospolitej, [w:] idem, Domus divisa: studia nad literaturą ruska w I Rzeczypospolitej, Kraków 2002, s. 59. Więcej na ten temat por. ibidem, s. 51-62.

25 Jak pisze Giovanna Brogi Bercoff, oba dzieła dobrze ilustrują to zjawisko, choć przypadki legitymizacji historycznej opartej na odwołaniu do dziedzictwa średniowiecznej Rusi były powszechne już w XVI i na początku XVII wieku w antykatolickich i antyuniackich dziełach polemicznych; G. Brogi Bercoff, Ruś, Ukraina, Ruthenia ..., s. 353-354. 
też za pośrednictwem grafiki książkowej ${ }^{26}$. Zdaniem Natalii Jakowenko i Teresy Chynczewskiej-Hennel nie tylko działalność wydawnicza, lecz także remontowo-odnowicielska Piotra Mohyły była wyrazem budowania „mostu między przeszłością i teraźniejszością", opierała się na przekonaniu o ciągłości wiary i świętości klasztoru kijowskiego ${ }^{27}$. Był to trud podjęty w celu przywrócenia rangi Kijowa jako duchowo-religijnego, kulturalnego, a z czasem politycznego centrum Rusi. Dlatego warto wskazać na mniej znane badaczom źródła paratekstowe, w których ta aktywność metropolity została wyeksponowana, wspomagając przez komemorację i pochwałę zamierzenia hierarchy i innych reformatorów w metropolii.

Przykładem posłużyć może spuścizna drukarska i piśmiennicza Michała Ślozki. W liście dedykacyjnym do Piotra Mohyły z Triodionu (Трішдіон, 1642) lwowski typograf chwalił metropolitę za odnowę miejsc świętych szczególnie ważnych dla Kościoła ruskiego, albowiem związanych z początkami ruskiego chrześcijaństwa. Chlubne świadectwo inicjatorowi owych restauracji wydawał przede wszystkim sobór Mądrości Bożej, doprowadzony do „pierwotnego stanu i piękna”. Była to świątynia przypominająca dawną wielkość Kijowa - centrum duchowo-religijnego Rusi, a wydawca sugerował powrót ośrodka nazwanego „miastem pod Bożą opieką" do tej roli w czasach Mohyły. Było to nawiązanie do „kijowskocentrycznego" konceptu, aktualnego w paratekstach druków kijowsko-peczerskich w pierwszej połowie XVII wieku ${ }^{28}$. Bohater laudacji został odbiorcom przedstawiony jako spadkobierca określonej tradycji:

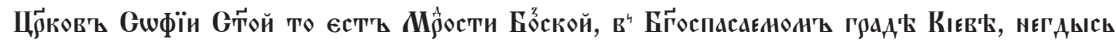

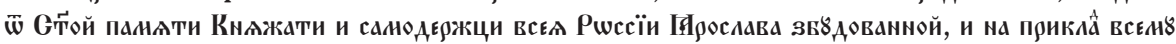

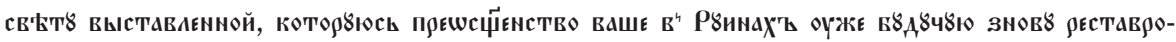

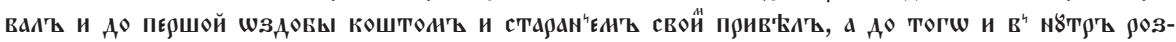

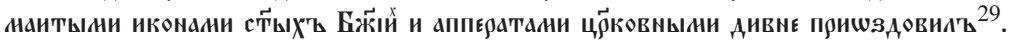

W dalszej części listu wydawca przypominał kolejne święte miejsca ważne dla tożsamości kolektywnej, przywołujące pamięć o książęcym Kijowie: remontowaną przez metropolitę Ławrę, odbudowaną cerkiew Dziesięcinną i inne świątynie:

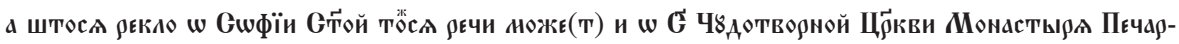

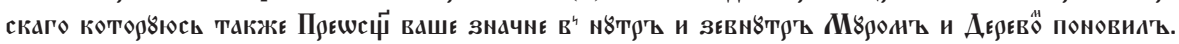





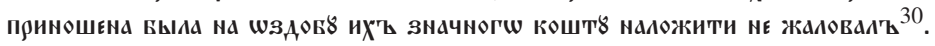

26 Por. A. Gronek, Konteksty ideowe przedstawień św. Włodzimierza w nowożytnej ukraińskiej grafice książkowej, [w:] O miejsce książki w historii sztuki, cz. 2. Państwo i Kościót. W rocznice chrztu Polski, red. A. Gronek, Kraków 2019, s. 165.

27 T. Chynczewska-Hennel, N. Jakowenko, Spoleczeństwo — religia..., s. 133.

$28 \mathrm{Na}$ temat tego konceptu por. Н. Яковенко, Символ «Богохранимого града», у пам'ятках київського кола (1620-1640-ві роки), [w:] еаdет, Паралельний світ..., s. 296-330.

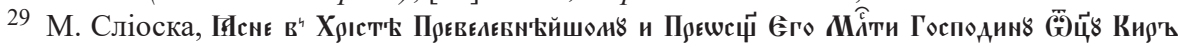

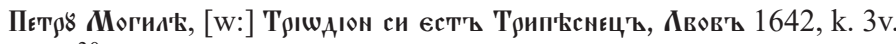

30 Ibidem. 
Zarówno prowadzona przez Mohyłę w Kijowie odnowa, jak i starania czynione $\mathrm{w}$ celu uwiecznienia tego dzieła za pośrednictwem drukowanej pochwały były częścią cerkiewnej reformy ${ }^{31}$, której budulcem stało się między innymi integrujące prawosławnych odwołanie do pamięci o przeszłości.

Druga tendencja mocno zarysowana $\mathrm{w}$ dedykacjach to pochwała ruskich szlachciców za lojalność wobec króla i zaangażowanie w rozwój życia politycznego w Rzeczypospolitej. Za ilustrację uznać można podziękowania dla władcy za patronat wydawniczy. Oprócz wskazanej praktycznej funkcji były one sposobem wyrażenia szacunku dla panującego i zamanifestowania przywiązania do Rzeczypospolitej lub Korony Polskiej — ojczyzny wielu narodów. W ten sposób budowano wizję wspólnej historii wielonarodowej i wielowyznaniowej Rzeczypospolitej, której pełnoprawnymi obywatelami byli/powinni być Rusini.

$\mathrm{W}$ przytoczonym liście dedykacyjnym do metropolity kijowskiego Piotra Mohyły, a także w innych lwowskich ofiarowaniach dla biskupów z domu Żeliborskich, Michał Ślozka skupił się na omówieniu podwójnych zasług hierarchów względem Cerkwi i ojczyzny zarazem. Przekonywał, że przodkowie lwowskich władyków otrzymali swój herb za walkę w obronie Korony Polskiej ${ }^{32}$. Najwięcej uwagi udziałowi Żeliborskich w życiu obywatelskim politycznym i religijnym w Rzeczypospolitej poświęcił jednak kijowski intelektualista Joanicjusz Galatowski w liście, który został dołączony do trzeciej edycji zbioru kazań Klucz rozumienia. W pochwale przywołał imiona zasłużonych dla ojczyzny przodków biskupa Atanazego, którzy pełnili w państwie ważne i odpowiedzialne polityczne funkcje, działali na forum sejmowym i sejmikowym, byli uczestnikami walk zbrojnych ${ }^{33}$. Ponadto byli skoligaceni z przedstawicielami takich wiernych królowi rodów jak Bałabanowie, Potoccy, Jarmolińscy i inni ${ }^{34}$. Należy pamiętać, że laudacje te wzmacniały poczucie wartości wśród prawosławnych wyznawców, były też istotne dla pozycji Kościoła wschodniego. W kontekście pamięci kulturowej warto zauważyć, że lwowska dedykacja Galatowskiego z 1665 roku wpisuje się w tendencję opisu rzeczywistości prezentowaną we wcześniejszych, między innymi paratekstowych, laudacjach dla hierarchów w metropolii kijowskiej. Znamienne jest jednocześnie to, że tekst uczonego związanego z kijowskim kolegium ukazał się, gdy w peczerskiej typografii pojawiły się pierwsze druki z dedykacjami kreującymi zupełnie inną wizję historii. Nie było tam już mowy o wiernej służbie

31 O Ślozce jako reformatorze por. A. Z. Nowak, Laudacje dla biskupów w spuściźnie pisarskiej i działalności Michała Ślozki - świeckiego wydawcy, „Latopisy Akademii Supraskiej” 9. Rola laikatu w życiu Cerkwi, 2018, s. 61-72.

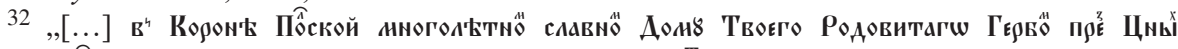

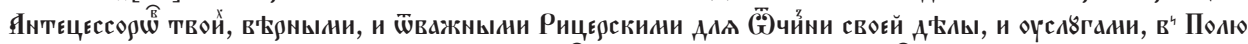

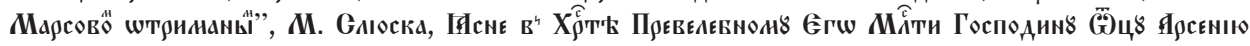
Желиворскон४, [พ:] Фпостол'ъ, Квов'ъ 1654, k. 3v.

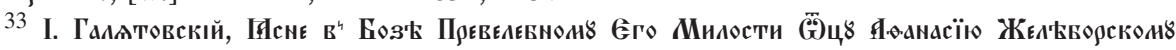

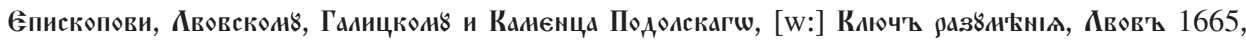
k. $3-4 \mathrm{v}$.

34 Ibidem, k. 4. 
królowi i Rzeczypospolitej — „miłej ojczyźnie swojej”35. W edycjach takich jak Pateryk kijowsko-peczerski (Патерїкъ или GЈтечникъ Печерскій) z 1661 roku, zbiór kaznodziejski Miecz duchowny $\left(M e u^{\natural} \partial \overrightarrow{x_{B}}\right.$ bы w teologicznej pracy archimandryty Innocentego Gizela Pokój z Bogiem człowiekowi (Миръ съ Бгогмъ чл̈вък४, 1669) na odwrocie strony tytułowej w miejscu szlacheckiego herbu znalazło się godło carskie z wierszem, a dalej - list dedykacyjny do cara ${ }^{36}$. Były to pierwsze drukowane w Lawrze księgi, w których sytuacja polityczna w czasach po ugodzie perejasławskiej oraz w przededniu i tuż po Andruszowie odcisnęła piętno na paratekstach ramy wydawniczej.

Rozmaite materiały paratekstowe otwierające księgę łączyła tendencja do opisu aktualnego życia prawosławnej społeczności ruskiej w powiązaniu z historią. Była to specjalnie modelowana wizja przeszłości, służąca bieżącym religijnym, kulturalnym, politycznym potrzebom, odpowiadająca na wyzwania rzucone w XVI-XVII wieku przez Zachód oraz na panującą w państwie sytuację. Upamiętnianie redaktora księgi, inicjatora wydania lub patrona edycji, niekiedy samego dzieła było często pretekstem do refleksji nad społecznie ważną rolą tego aktu (między innymi integrowanie wokół wskazanego przewodnika, rozpowszechnienie wzorca osobowego czy też preferowanej wersji przebiegu dawnych wydarzeń) i zarazem sposobem uwieczniania. Dlatego warto podkreślić, że parateksty ksiąg drukowanych — także tych, których zasadnicza część pełniła cerkiewną, a czasem stricte liturgiczną funkcję - są wartościowym źródłem do prowadzenia badań dotyczących kolektywnej tożsamości, budowanej przez ówczesne elity intelektualne na podstawie propagowanych wyobrażeń na temat własnej przeszłości.

\section{Bibliografia}

Âkovenko N., Dzerkala identičnostì. Doslidžennâ z istorï uâvlen' ta idej v Ukraïnì XVI-počatku XVII stolittâ, Laurus, Kiïv 2012.

Âkovenko N., Latina na službì kiêvo-rus'kij istorï (,,Camoneae Borysthenides”, 1620 rìk), [w:] eadem, Paralel'nij svit. Doslidžennâ z istorï̈ uâvlen' ta ìdej v Ukraïnì XVI-XVII st., Kritika, Kiïv 2002.

Âkovenko N., Simvol «Bogohranimogo grada», u pam'âtkah kï̈vs'kogo kola (1620-1640-vì roki), [w:] eadem, Paralel'nij svit. Doslìžennâ z istorï uâvlen' ta ìdej v Ukraïnì XVI-XVII st., Kritika, Kiïv 2002.

Âkovenko N., Topos „Z êdnanih narodìv u panegìikah knâzâm Ostroz'kim ì Zaslavs'kim”, [w:] eadem, Paralel'nij svit. Doslidžennâ z istoriï uâvlen' ta idej v Ukraïnì XVI-XVII st., Kritika, Kiïv 2002.

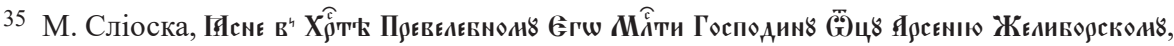
[w:] Япостол'ъ, Авов'ъ 1654, k. 4.

$36 \mathrm{Na}$ ten temat Ю. Шустова, Государственная симоволика в геральдических композииях книг киевской и московской печати 60-годов XVII в., [w:] Человек в культуре русского барокко, red. М. С. Киселева, Москва 2007, s. 225-233. Władza cara w przeciwieństwie do królewskiej jest sakralizowana, na ten temat por. M. Melnyk, Problematyka antropologiczna w pismach Piotra Mohyły, Olsztyn 2005, s. 244. Tam też literatura przedmiotu. 
Blagověrnomu i světlosiâûsêmu Velmožnomu Êgo Gospodarskoj Milosti İo Mironu Br"navskomu, Voêvodě Moldovlahïa. Bl(a)goslovenstva B(o)žogo, dolgolětnogo zdorovâ, ŝaslivogo povoženâ prosât" i userdno želaût", [w:] Oktoih" sirěč" Osmoglasnik". Tvorenïe pr(epodo)bnago otca našego Ioanna Damaskina i procïh B(o)goduhnovennyh" S(vâ)tih" Otec", Lvov" 1630.

Borek P., Ruś w Kronice Macieja Stryjkowskiego, [w:] Szlakami dawnej Ukrainy. Studia staropolskie, Collegium Columbinum, Kraków 2002.

Brogi Bercoff G., Ruś, Ukraina, Ruthenia, Wielkie Księstwo Litewskie, Rzeczpospolita, Moskwa, Rosja, Europa Środkowo-Wschodnia: o wielowarstwowości i polifunkcjonalizmie kulturowym, [w:] Contributi italiani al XIII Congresso Internazionale degli Slavisti (Ljubljana 15-21 agosto 2003), red. A. Alberti, M. Garzaniti, S. Garzonio, Firenze University Press, Firenze 2014.

Chynczewska-Hennel T., Jakowenko N., Społeczeństwo - religia - kultura, [w:] Między soba. Szkice historyczne polsko-ukraińskie, red. T. Chynczewska-Hennel, N. Jakowenko, Instytut Europy Środkowo-Wschodniej, Lublin 2000.

Galâtovskìj İ., Âsne v" Bozě Prevelebnomu Êgo Milosti Otcu Af̀anasïû Želěborskomu Êpiskopovi, Lvovskomu, Galickomu i Kamênca Podolskago, [w:] idem, Kluč" razuměniâ, Lvov" 1665.

Goff J. Le, Historia i pamięć, przeł. A. Gronowska, J. Stryjczyk, Wydawnictwo Uniwersytetu Warszawskiego, Warszawa 2007.

Gronek A., Konteksty ideowe przedstawień św. Włodzimierza w nowożytnej ukraińskiej grafice ksiązkowej, [w:] O miejsce ksiązki w historii sztuki, cz. 2. Państwo i Kościół. W rocznicę chrztu Polski, red. A. Gronek, Muzeum Narodowe w Krakowie, Kraków 2019.

Kruk M. P., ,,Oktoich lwowski” z 1630 r. Historyczne i kulturowe związi między Rzeczapospolita, Mołdawia i Księstwem Moskiewskim, „Porta Aurea” 7-8, 2009.

Loewe I., Gatunki paratekstowe w komunikacji medialnej, Wydawnictwo Uniwersytetu Śląskiego, Katowice 2007.

Melnyk M., Problematyka antropologiczna w pismach Piotra Mohyty, Wydawnictwo Uniwersytetu Warmińsko-Mazurskiego w Olsztynie, Olsztyn 2005.

Napiórkowski M., Upamiętnienie, [w:] Modi memorandi. Leksykon kultury pamięci, red. M. Saryusz-Wolska, R. Traba, współp. J. Kalicka, Wydawnictwo Naukowe Scholar, Warszawa 2014.

Naumow A., Prawosławni święci I Rzeczypospolitej, [w:] idem, Domus divisa: studia nad literatura ruska w I Rzeczypospolitej, Collegium Columbinum, Kraków 2002.

Nowak A. Z., Laudacje dla biskupów w spuściźnie pisarskiej i działalności Michała Ślozki —świeckiego wydawcy, „Latopisy Akademii Supraskiej” 9. Rola laikatu w życiu Cerkwi, 2018.

Ogîenko İ., Istoriâ ukraïns'kogo drukarstva, Naša Kul'tura ì Nauka, Kiïv 2007.

Paprocki B., Herby rycerstwa polskiego, w drukarni Macieia Garwolczyka: za staraniem własnym y nakładem autora, Kraków 1584, https://polona.pl/item/herby-rycerztwa-polskiego-napiecioro-xiag-rozdzielone,NjcyNTM5NTQ/391/\#item.

Plohìj S., Vìd knâzâ do get'mana. Obraz ,protektora” v ukrä̈ns'komu pravoslavnomu pis'menstvì (druga polovina XVI-peršì desâtilittâ XVII st.), [w:] Osâgnennâ istorï̈: Zbìrnik prac' na pošanu profesora M.P. Koval's'kogo, red. L. Vinar, İ. Pasì̌nik, Ostroz'ka akademîa, Ukraïns'ke ìstorične tovaristvo, Ostrog-N'û-Jork 1999.

Rička V. M., Prigaduvannâ Rusì (osmislennâ spadŝini sv. Volodimira v ukraïns'kì suspil'nopolitičnij dumcì XVII st.), „Ukraïns'kij ìstoričnij žurnal” 2012, nr 1.

Saryusz-Wolska M., Wprowadzenie, [w:] Pamięć zbiorowa i kulturowa współczesna perspektywa niemiecka, red. M. Saryusz-Wolska, Universitas, Kraków 2009.

Slìoska M., Âsne v" Hristě Prevelebnějšomu i Preosvâsenomu êgo Milosti Gospodinu Otcu Kir" Petru Mogilě, [w:] Trìodion si êst" Tripěsnec", Lvov" 1642.

Slìoska M., Âsne v" Hristě Prevelebnomu Êgo Milosti Otcu Arseniju Želiborskomu, [w:] Apostol", Lvov" 1654.

[Smotrickij] G. D., Vsâkago čina pravoslavnyj čitatelû, [w:] Biblïa sirěč Knigy Vethago i Novago Zavěta, po âzyku slovensku, Ostrog" 1581.

Slavica Wratislaviensia 173, 2020

(C) for this edition by CNS 
Šustova Û., Gosudarstvennaâ simovolika v geral'dičeskih kompozicâh knig kievskoj i moskovskoj pečati 60-godov XVII v., [w:] Čelovek v kul'ture russkogo barokko, red. M. S. Kiseleva, Institut filosofii RAN, Moskva 2007.

Tobaszewska J., Od literatury jako medium pamięci do poetyki pamięci. Kategoria pamięci kulturowej w badaniach nad literatura, „Pamiętnik Literacki” 104, 2013, z. 4.

Traba R., Wstęp, [w:] J. Assmann, Pamięć kulturowa. Pismo, zapamiętywanie i polityczna tożsamość w cywilizacjach starożytnych, przeł. A. Kryczyńska-Pham, wstęp i red. R. Traba, Wydawnictwa Uniwersytetu Warszawskiego, Warszawa 2008.

\section{Paratexts of Printed Church Books in Kyiv Metropolitanate as Memory Media (Second Half of the 16th and the 17th Centuries)}

\section{Summary}

Paratexts which opened Cyrillic printed books in the Kyiv Metropolitanate commemorated the patrons, or authors, of these editions. The analysis of sources such as letters of dedication and prefaces carried out in the article shows that they were considered as a carrier medium of memory, thanks to which it was possible to build a collective identity. Its basis was a specially modelled vision of history, which at that time served important religious, cultural and even political needs.

Keywords: paratext, print, laudation, commemorating, history

\section{Паратексти друкованих церковних книг в Київській митрополії як медіум пам'яті (друга половина XVI-XVII століття)}

Резюме

Головним завданням паратекстів (листів-присвят, передмов тощо), якими зазвичай розпочиналися кириличні книги, надруковані у Київській митрополії, було уславлення меценатів цих видань. Здійснений у статті аналіз показує, що ці тексти розглядалися їхніми авторами як медіум пам'яті, опираючись на який будувалася колективна ідентичність тогочасного руського суспільства. Ї̈̈ основою було спеціально змодельоване бачення історії, яке ставало підгрунтям для інтерпретації та пояснення актуальних релігійних, культурних і навіть політичних подій.

Ключові слова: паратекст, друк, лаудація, комеморація, історія 